\title{
KOMUNIKASI MASSA DALAM SIARAN RADIO
}

Oleh :

\author{
Ni Nyoman Ayu Wilantari \\ wilantari@iahntp.ac.id
}

\begin{abstract}
Storytelling or storytelling has become an oral culture in Indonesian society this oral culture or tradition is a hereditary heritage. The times are getting more advanced and radio is present as a mass media that facilitates the oral culture. Radio is a means of mass media communication or often referred to as mass communication. Radio in broadcasting has broadcasters as the most important position in the success of a program that they make. Fast and direct, familiar with the listener, warm, simple, unlimited, inexpensive, able to repeat and flexible entertainment facilities which are the advantages of radio, while fleeting, global, time-limited, linear, contain disturbances in broadcasting and are local to radio shortages..
\end{abstract}

Kata Kunci : Komunikasi massa, Radio, Penyiar

\section{PENDAHULUAN}

Indonesia memiliki tradisi atau budaya yang unik dalam kehidupan masyarakatnya, budaya tersebut adalah budaya lisan yang sudah mendarah daging dari zaman nenek moyang masyarakat Indonesia. Mereka terbiasa menceritakan atau mendongeng apapun yang ada disekitar mereka baik itu mendongeng tentang alam, dongeng tentang binatang maupun mendongeng tentang alam semesta sebagai pengantar tidur anak-anak atau cucu-cucu mereka. Budaya lisan ini menjadi turun temurun hingga kini, orang-orang Indonesia lebih suka mendengar secara lisan informasi yang dibicarakan dan bukan melalui tulisan. mereka lebih cepat mengerti dan mendapatkan informasi itu melalui pendengaran mereka.

Radio hadir ditengah-tengah masyarakat sebagai sarana bertutur modern karena naskah radio yang dibuat sedemikan rupa melalui proses bertutur dari pembuat naskah dengan cara bersuara menceritakan hal yang ingin ditulisnya, dalam keadaan ini penulis naskah seakan-akan berhadapan dengan orang lain karena naskah radio tersebut merupakan tuntutan untuk 
dikonsumsi oleh telinga pendengarnya ( Yulia, 2010 : 94). Radio juga merupakan sarana hiburan yang murah, menyajikan beragam jenis suara dari musik, lagu, berita hingga pencarian sesuatu atau seseorang. dalam melakukan siarannya radio dilengkapi perangkat-perangkat untuk mentransmisikan siaran sehingga bisa didengar oleh masyarakat luas dimanapun mereka berada. Peran penyiar radio memiliki posisi penting dalam melakukan siaran radio karena penyiarlah yang akan menyampaikan informasi ataupun memutarkan lagulagu serta musik sebagai sarana hiburan.

Menurut Romli, 2011 : 17, penyiar melakuan siaran bukan atas kepentingan pribadinya melainkan mewakili stasiun radionya sehingga apa yang penyiar sajikan sudah memiliki visi, misi, program, style, standarisasi bahasa, serta kriteria informasi dan musik radionya. Didalam siaran radio yang dilakukan penyiar radio terdapat komunikasi yang disebut dengan komunikasi massa yang merupakan kependekan dari komunikasi media massa. Media massa secara garis besarnya terbagi atas media massa cetak dan media massa elektronik. Media massa cetak berupa koran, buku, majalah serta tabloid sedangkan media massa elektronik berupa televisi serta radio. Namun seiring perkembangan teknologi di dunia ada lagi penambahan media yang dikatakan sebagai media gabungan karena media ini dapat berupa tulisan dan juga suara. Media ini dinamai media massa internet yang dapat diakses oleh seluruh masyarakat dunia tanpa mengenal batas ruang dan waktu. Radio siaran sekarangpun sudah bisa didengarkan melalui internet dengan media laptop ataupun Hp tanpa harus mempergunakan pesawat radio konvensional.

\section{PEMBAHASAN}

\subsection{Komunikasi Media Massa}

Hidup di era milenial saat ini, kita dikeliling berbagai jenis media massa baik yang berupa media elektronik maupun media cetak. Media massa berupa sebuah sarana untuk memberikan informasi kepada masyarakat atau khalayak luas agar apa yang terjadi di suatu tempat dapat diketahui oleh orang - orang yang tidak berada di tempat kejadian tersebut. Di dalam media massa ada penyampaian pesan dari pembuat berita (komunikator) dan ada pula penerima berita (komunikan) proses itu disebut dengan komunikasi.

Komunikasi banyak macamnya tetapi yang akan dibahas disini adalah komunikas media massa atau sering disebut sebagai komunikasi massa. Istilah dari komunikasi massa diadopsi dari bahasa Inggris mass communication yang merupakan kepedendekan kata dari mass media communication yang diartikan sebagai komunikasi yang menggunakan media massa (Ngalimun, 2017 : 89). Fungsi dari komunikasi massa agar informasi yang ada dapat disebarluaskan sehingga 
pendidikan dapat merata disemua daerah, pertumbuhan ekonomi dapat ditingkatkan, dan kegembiraan dapat tercipta didalam hidup seseorang. Banyak perubahan fungsi komunikasi massa yang terjadi akibat dari perkembangan teknologi komunikasi di bidang penyiaran dan audiovisual ( Cangara, $2011: 61)$.

\section{Inspirasi perkembangan}

komunikasi massa bersumber dari formula Harold D. Lasswel (1948) yaitu Who Say what in wich chanel to whom with what effect ? yang berarti siapa berkata apa melalui saluran apa kepada siapa dengan efek apa ? siapa dalam hal ini yang dimaksud adalah komunikator, berkata apa adalah pesan, melalui saluran apa yaitu media, kepada siapa komunikan, dengan efek apa adalah akibat. Media massa merupakan sarana penting untuk menyampaikan pesan agar bisa mempengaruhi massa ( Syahputra, $2016: 61$ ).

Noegroho, $2010: 8$ menyatakan teknologi sudah pasti dipergunakan dalam menjalankan peran dari komunikasi massa di dalam masyarakat luas. Masyakarakat informasi memiliki ciri yaitu semakin mendominasinya sektor informasi dalam kehidupan masyarakat. Penyimpanan, produksi, pengolahan, penerapan dan penyampaian informasi kuantatif ataupun kualitatif sudah semakin maju.

Sean MacBride (1980) dalam Cangara, 2011 : 62 mengemukakan komunikasi tidak hanya dapat diartikan sebagai pertukaran berita dan pesan, akan tetapi dapat juga sebagai kegiatan individu dan kelompok mengenai pertukaran data, fakta, dan ide. Sehingga komunikasi massapun dapat berfungsi sebagai informasi yang berarti suatu kegiatan menyimpan data, me gumpulkan, fakta dan pesan, opini dan komentar. Agar khalayak dapat mengetahui apa yang terjadi diluar dirinya, apakah itu dalam lingkungan daerah tempat tinggalnya atau daerah lain, di tingkat Nasional maupun di tingkat Internasional. Komunikasi massa atau komunikasi media massa juga berfungsi sebagai sosialisasi, berfungsi juga untuk motivasi, berfungsi sebagai bahan diskusi, berfungsi sebagai sarana pendidikan, berfungsi untuk memajukan kebudayaan, berfungsi sebagai hiburan serta berfungsi sebagai integritas.

Ciri-ciri Komunikasi Massa adalah komunikasi berlangsung satu arah (one-way communication) yang diartikan tidak adanya arus balik dari komunikan kepada komunikator. Wartawan atau penyiar sebagai komunikator tidak dapat mengetahui tanggapan para 
pembaca atau pendegar serta penonton terhadap pesan atau berita yang disajikannya dalam media massa. Adapun ciri kedua dari komunikasi massa adalah komunikator pada komunikasi massa melembaga, dapat diartikan suatu media massa sebagai saluran komunikasi massa merupakan lembaga, yakni suatu institusi atau organisasi. Komunikator pada komunikasi massa, dapat disebut wartawan surat kabar dalam media massa cetak atau penyiar televisi serta penyiar radio, media yang dipergunakannya itu adalah suatu lembaga yang menyebarluaskan pesan komunikasinya dan bertindak atas nama lembaga. Lebih lanjut dibahas disini ciri ketiga dari komunikasi massa yaitu pesan pada komunikasi massa bersifat umum, dapat diartikan pesan yang disebarkan melalui media massa tersebut bersifat umum, sasarannya ditujukan kepada umum serta untuk kepentingan umum. Selanjutnya masuk pada ciri keempat dari komunikasi massa yaitu media massa atau media komunikasi massa menimbulkan keserempakan, artinya kemampuan media massa menimbulkan keserempakan khalayak dalam menerima pesan-pesan yang disebarkan. Pembahasan terakhir dari ciri- ciri komunikasi massa yaitu masuk pada ciri kelima disebutkan bahwa komunikaan dari komunikasi massa bersifat heterogen, artinya anggota masyarakat yang terlibat dalam proses komunikasi massa sebagai sasaran yang dituju komunikator berada terpencarpencar, diantara mereka sebagai penikmat sajian media massa tidak saling mengenal serta tidak memiliki kontak pribadi, mereka juga memiliki jenis kelamin yang berbeda-beda, usia yang berbeda, agama yang berbeda, ideologi atau paham kebangsaan yang berbeda, pekerjaan berbeda, pendidikan berbeda, pengalaman dalam hidup berbeda, kebudayaan berbeda, keinginan dan cita-cita berbeda, serta lain sebagainya ( Effendy, 2011: 22-25)

Dijelaskan lagi oleh Nurudin, 2009 : 21 bahwa komunikator dalam komunikasi massa merupakan suatu lembaga dikarenakan elemen utama dalam komunikasi massa tersebut adalah media massa. Media massa hanya bisa muncul atau ada di masyarakat atau khalayak penerima pesan karena gabungan kerjasama dengan beberapa orang. Komunikasi massa tidak sama bentuknya dengan komunikasi- komunikasi yang lainnya, dapat diambil contoh komunikasi antarpribadi, orang yang ada terlibat didalam komunikasi antarpribadi berkeinginan tanpa paksaan atau inisiatif sendiri ketika mengadakan komunikasi, tanpa adanya aturan tertentu seperti yang diisyaratkan didalam proses komunikasi massa.

$$
\text { Vivian, } 2008 \text { : } 450-451
$$

menyatakan, komunikasi massa adalah proses yang dipergunakan oleh komunikator massa untuk mengirimkan pesan kepada khalayak penerima pesan massa (komunikan). Kemampuan untuk 
menjangkau bayak orang dari ribuan bahkan hingga jutaan merupakan ciri utama komunikasi massa. Lebih lanjut dikatakan komunikasi yang dilakukan melalui media massa modern dapat meliputi surat kabar sebagai media massa cetak lalu yang memiliki jangkauan yang lebih luas berupa siaran radio serta siaran TV dan film- film di gedung- gedung bioskop yang diperuntukkkan pada masyarakat penerima pesan ( Yulia, 2010 : 15).

Sebuah era baru berupa era informasi teknologi kini memberikan peluang kerja di bidang komunikasi dan informasi melalui media massa yang meresap kedalam kehidupan masyarakat atau khalayak penerima pesan dan berdampak pada perilaku mereka. Komunikasi sendiri merupakan warisan yang memiliki sifat interdisipliner serta merupakan tempat pakar terdahulu berupa disiplin ilmu yang menguntungkan diperoleh dari pendekatan humaniora dan ilmu perilaku yang merupakan suatu bidang studi yang menjadikan media perhatian yang terus berlanjut dari waktu ke waktu ( Ruben \& Stewart, 2017 : 3237). Massa memiliki arti orang banyak dan mereka tidak harus berada dilokasi yang sama karena mereka dapat tersebar atau berpencar di berbagai lokasi, degan waktu yang bersamaan atau hampir bersamaan dan memperoleh pesan komunikasi yang sama melalui media massa ( Ngalimun, 2017 : 90).

Grifin dalam Hasrullah, 2013 : 53-55 menyatakan komunikasi massa terbagi atas dua pokok bahasan, yaitu media and culture seta media effects. Dalam Media and culture terdapat pernyataan dari Marshall McLuhan, kemajuan teknologi komunikasi dari huruf, bunyi, mesin cetak dan telegraf telah mengubah proses pengalaman sensorik kita secara radikal.Pernyataan lebih lanjut mengenai culture studies dilontarkan oleh Stuart Hall yang berisi tentang fungsi media menjaga ideologi yang mempunyai kekuasaan. Media effect dari George Gerbner, televisi telah menjadi pencerita kisah yang dimiliki masyarakat. Agenda setting berita dan framing gambaran- gambaran yang ada ada telah diseleksi oleh kepala kita.

Komunikasi Massa adalah proses untuk mencipatakan kesamaan arti antara media massa dengan masyarakat luas. Komunikasi massa tidak dapat disamakan dengan bentuk komunikasi lainnya, karena dalam komunikasi massa terdapat timbal balik yang masih samar atau tidak jelas. Dapat dicontohkan dengan perolehan rating sebuah acara di media massa elektronik yang memerlukan waktu paling cepat satu hari hingga satu bulan. 
Lain halnya dengan komunikasi interpersonal yang merupakan komunikasi yang dilakukan oleh dua orang atau lebih secara tatap muka maka orang - orang tersebut dengan cepat dapat melihat timbal balik dari komunikasi yang mereka lakukan ( Baran, $2011: 7$ ).

\subsection{Radio Sebagai Media Massa Elektronik}

Masyarakat Indonesia sangat akrab dengan radio, karena radio adalah hiburan yang lebih murah jika dibandingkan dengan televisi. Selain itu radio juga memilki jaringan yang kuat hingga mampu menembus daearahdaerah pedalaman atau daerah yang berada jauh di dalam hutan maupun dikaki gunung. Radio siaran merupakan salah satu bentuk dari media massa yang memiliki keunikan tersendiri, hingga saat ini belum sepenuhnya dimiliki oleh media massa lain. Adapun bentuk keunikannya itu selain merupakan komunikasi massa radio juga bisa menjadi komunikasi antarpribadi. Karena penyiar radio selalu berusaha menyapa pendengarnya dengan hangat dan bersahabat( Yulia, $2010: 16)$.

$$
\text { McQuail (1987) (dalam }
$$

Ngalimun, 2017 : 91-92), menyebutkan institusi lembaga yang mempergunakan media, dalam pembahasan ini adalah media elektronik yaitu radio yang sarana komunikasinya pada publik adalah melembaga memiliki ciri-ciri yaitu menyediakan saluran untuk menghubungkan orang tertentu dengan orang lain, memproduksi dan mendistribusikan pengetahuan berwujud informasi, pandangan, dan budaya, sebagian besar kegiatan media berada dalam lingkungan public serta merupakan institusi yang terbuka bagi semua orang untuk berperan sebagai pengirim ataupun penerima pesan, industry media memiliki ketergantungan terhadap imbalan kerja, teknologi maupun kebutuhan pembiayaan.

Di dalam siaran radio sudah pasti ada keungulan maupun kekurangannya, keunggulan dari radio yaitu cepat dan langsung karena reporter radio tidak memerlukan banyak perangkat untuk melaporkan berita di lapangan, mereka cukup berbicara melalui saluran telepon secara langsung. Keunggulan berikutnya radio itu akrab dengan pendengarnya, karena orang jarang berkumpul bersama untuk hanya sekedar mendengarkan radio biasanya radio didengarkan secara personal disaat santai, memasak di dapur ataupun saat mengendarai mobil. Radio itu hangat karena mampu menyentuh sisi hati dan jiwa 
seseorang melalui paduan katakata, musik serta efek suara dalam siarannya. Radio juga dikategorikan alat penghibur yang sederhana, tanpa batas, murah, bisa mengulang dan fleksibel. Kekurangan dari radio adalah selintas yang diartikan siaran radio diakses cepat dan juga cepat hilang lalu dilupakan, radio bersifat global atau menyeluruh dan tidak detail dalam penyampaian beritanya, batasan waktu, linier, mengandung gangguan biasanya akibat cuaca yang buruk maka suara terdengar timbul tenggelam, radio juga memilki kekurangan yaitu bersifat lokal ( Romli, 2009 : 19-21 )

Sasaran komunikasi massa melalui radio adalah pendengar atau penikmat siaran radio itu, komunikasi massa dapat dikatan berjalan secara efektif apabila pendengar terpikat perhatianya pada siaran radio yang sedang berlangsug. Sifat dari pendengar radio itu adalah heterogen berpencar daerahnya, jenis kelamin, pendidikan dan kebudayaannya, sifat lainya yaitu ribadi, aktif, dan selektif ( Yulia, 2010 : 75-77). Dalam melakukan siaran radio seorang penyiar dibantu oleh beberapa perangkat sehingga siaran radio dapat di dengar oleh khalayak luas. Adapun perangkat siaran tersebut antara lain pemancar, ruang siaran, ruang produksi, radio console atau mixer, microphone dan headpone, monitor studio, $\mathrm{CD}$ Player dan tape, kabel audio, power amplifier serta distribution amplifier ( Romli, 2009 : 22-24).

\subsection{Penyiar Memilliki Posisi Terpenting Dalam Siaran Radio}

Suara penyiar radio yang unik, indah dan renyah dapat menjadi ciri khas mereka didalam melakukan siaran. Penikmat siaran radio akan dengan mudah mengetahui siapa yang sedang melakukan siaran hanya dengan mendengar kekhasan suara penyiar. Radio diciptakan memang sebagai sarana untuk didengarkan dalam memberikan informasi kepada khalayak luas dan radio juga identik dengan musik. Musik sangat nyaman saat dinikmati dengan cara mendengar, musik dapat menimbulkan sebuah rasa dan ketenangan pada diri seseorang yang menikmatinya melalui pendengaran sehingga tidak sedikit yang tertidur saat menikmati musik. Kembali kepada penyiar yang melakukan siaran radio, mereka sebelum diterima sebagai penyiar di sebuah stasiun radio pastilah melakukan serangkaian tes agar diterima bekerja disana. Adapun syarat sebagai penyiar yaitu suara emas ( golden voice) yang dapat dibentuk melalui latihan pernafasan, teknik vokal, memilki imajinasi yang tinggi tentang sosok- 
sosok pendengarnya dan juga topiktopik pembicaraan yang tidak kering sehingga dapat dipahami oleh khalayak luas sebagai pendengarnya ( Romli, 2009 : 38 ). Seorang penyiar radio tiadak diperbolehkan untuk menampakkan kesedihannya disaat siaran walaupun mereka sedang bersedih. Penyiar radio harus netral dalam membawa suasana hatinyan saat mereka siaran agar urusana pribadi dan urusan pekerjaan tidak bercampuraduk. Seorang penyiar harus selalu gembira sehingga mereka terkesan tidak memiliki beban dalam hidupnya ( Yulia, $2010: 20)$.

Menurut Ben G. Henneke ( 1954) dalam Romli, 2009 : 38, menyatakan seorang penyiar radio harus memiliki komunikasi gagasan, komunikasi kepribadian, proyeksi kepribadian yang meliputi keaslian, lincah, ramah serta sanggup menyesuaikan diri, disebutkan lagi kecakapan penyiar itu berupa pengucapan yang jelas dan benar atas setiap kata yang dikemukakan dan memiliki control suara yang meliputi pola titi nada, kerasnya suara, tempo, dan kadar suara.

Dalam hal ini penyiar juga harus selalu siap ditempatkan pada program acara apa saja serta kapan saja sehingga penyiar dituntut untuk mampu menguasai keseluruhan program siaran. Penyiar juga diharuskan memiliki wawasan yang luas sehingga penyiar itu harus rajin membaca Koran yang terbit harian, majalah, artike-artikel apapun isinya, buku, serta menonton acara atau berita di televisi sehingga informasi yang dimiliki seorang penyiar selalu yang terbaru atau up to date. Penyiar radio juga wajib memyukai musik dan lagu karena radio juga dikatakan sebagai music box, serta penyiar juga harus tahu tentang penyanyi-penyanyi serta lagu mereka. Penyiar juga harus mampu membuat suasana yang hangat dengan kekocakan mereka sehingga menghibur pendengarnya. Penyiar harus mampu berakting saat siaran mereka berlangsug, mereka harus memberikan kesan suara yang gembira serta bahagia walaupun tidak sama dengan suasana hati mereka yang sedih ataupun marah. Peyiar juga diharapkan enak dipandang, karena terkadang penyiar radio juga melakukan siaran out door atau diluar ruangan. Enak dipandang seorang penyiar tidak hanya diartikan berwajah ganteng atau cantik tetapi dengan memberikan senyum yang ramah dan tulus, hangat serta bersahabat pada penikmat suara mereka dan bersahaja dalam hal berpakaian serta bersih maka sudah menunjukan seorang yang enak dipandang ( Romli, 2009 : 39-40)

Penyiar melakukan siaran untuk didengar oleh telinga maka penulisan naskah siaran radio tidak sama dengan naskah penulisan di surat kabar atau media cetak lainnya. Penulisan naskah siaran radio ditulis seperti apa yang hendak dibicarakan ataupun ditulis 
seperti apa yang ingin didengar ( Yulia, 2010 : 93). Mendengar penyiar radio disaat mereka siaran bagaikan berbicara spontan tanpa kekakuan dari suara mereka walaupun apa yang mereka sampaikan itu sudah berbentuk naskah yang disusun sedemikian rupa agar menjadi naskah atau tulisan untuk dikonsumsi oleh telinga kita.

\section{SIMPULAN}

Komunikasi massa dalam siaran radio bisa dikatakan sebagai sarana bertutur modern karena masyarakat Indonesia sudah sangat akrab dengan tradisi atau budaya tutur sebagai warisan dari nenek moyang kita. Komunikasi massa dalam radio hadir memberikan informasi untuk dikonsumsi telinga kita dan berfungsi agar informasi yang ada dapat disebarluaskan kepada masyarakat atau publik. Radio memiliki keunggulan (cepat dan langsung, akrab dengan pendengarnya, hangat, alat penghibur yang sederhan, tanpa batas, murah, bisa mengulang dan fleksibel ) dan kekurangan (selintas, global, batasan waktu, linier, mengandung gangguan didalam melakukan siarannya dan bersifat lokal ). Radio dalam melakukan siarannya memiliki penyiar sebagai posisi terpenting dalam kesuksesan suatu program acara yang mereka buat. Seorang penyiar radio tidak diperbolehkan untuk menampakkan kesedihannya disaat siaran walaupun mereka sedang bersedih, mereka harus nampak netral dan tanpa masalah pribadi.

\section{DAFTAR PUSTAKA}

Baran, Stanley J. (2011). Pengantar Komunikasi Massa Literasi Media dan Budaya, Jakarta : Salemba Humanika.

Cangara, H. Hafied. (2011). Pengantar Ilmu Komunikasi. Jakarta : Raja Grafindo Persada.

Effendy, OnongUchjana.( 2011). Komunikasi Teori dan Praktek. Bandung : Remaja Rosdakarya.

Hasrullah. (2013). Beragam Perspektif Ilmu Komunikasi. Jakarta : Kencana Prenada Media Group.

Ngalimun. (2017). Ilmu Komunikasi Sebuah Pengantar Praktis. Yogyakarta : Pustaka Baru Press.

Noegroho, Agoeng. (2010). Teknologi Komunikasi, Yogyakarta : Graha Ilmu.

Nurudin . (2009). Pengantar Komunikasi Massa. Jakarta : PT. Raja Grafindo Persada.

Romli, Asep Syamsyul M. (2009). Dasar - Dasar Siaran Radio Basic Announcing, Bandung : Nuansa.

Ruben Brent D dan Stewart Lea P.( 2017). Komunikasi dan Perilaku Manusia. Jakarta : PT. Raja Grafindo Persada.

Syahputra Iswandi. ( 2016). Ilmu Komunikasi Tradisi, Perspektif dan Teori. Yogyakarta : Calpulis. 
Vivian, Jhon. (2008). Teori Komunikasi Massa. Jakarta : Kencana Prenada Media Group.

Yulia, Wanda ( 2010). Andai Aku Jadi

Penyiar, Yogyakarta : C.V Andi Offset. 